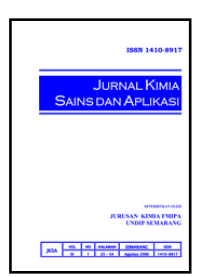

\title{
Isolasi dan Karakterisasi Kitinase Isolat Jamur Akuatik Kitinolitik KC3 dari Kecoa (Orthoptera)
}

\author{
Karso $^{\text {a }}$, Wuryanti ${ }^{\mathrm{a}^{*}}$, Sriatun ${ }^{\mathrm{a}}$ \\ a Chemistry Department, Faculty of Sciences and Mathematics, Diponegoro University, Jalan Prof. Soedarto, Tembalang, Semarang
}

Corresponding author: wuryanti@live.undip.ac.id

\begin{tabular}{l}
\hline Article Info \\
\hline \\
\hline Keywords: \\
chitinases, N- \\
acetylglucosamina, \\
KC3 aquatic fungi, \\
cockroach
\end{tabular}

\begin{abstract}
The isolation and characterization of chitinase from the chitinolytic aquatic fungal isolate $\mathrm{KC} 3$ from isolation of cockroach carcasses have been performed. The objective of this study was to obtain chitinase from $\mathrm{KC} 3$ aquatic fungal isolates and to obtain isolated chitinase characterization information that included optimum $\mathrm{pH}$ and optimum temperature. Chitinase is a complex enzyme composed of endocytinase, kitobiosidase and $\mathrm{N}$-acetylglucosaminidase. The production medium contained choloidal chitin as an inducer. Fractionation was done with ammonium sulfate to a saturation level of $90 \%$ (F5). Chitinase activity was measured by Ueda-Arai method based on substrate reduction. The highest specific activity was obtained at fraction one (F1) that was equal to $73.258 \mathrm{U} / \mathrm{mg}$. The chitinase characterization result was obtained by optimum chitinase $\mathrm{pH}$ profile at $\mathrm{pH} 3.8$ whereas the temperature profile obtained two peaks at $28,5^{\circ} \mathrm{C}$ and $29,5^{\circ} \mathrm{C}$. The temperature profile of the two peaks/dots indicated if there were two possible types of chitinase in the enzyme under test.
\end{abstract}

\section{Abstrak}

Kata Kunci:

kitinase, $\mathrm{N}-$ asetilglukosamin, jamur akuatik $\mathrm{KC}_{3}$, kecoa
Isolasi dan karakterisasi kitinase dari isolat jamur akuatik kitinolitik $\mathrm{KC} 3$ hasil isolasi bangkai kecoa telah dilakukan. Penelitian ini bertujuan untuk mendapatkan kitinase dari isolat jamur akuatik KC3 dan mendapatkan informasi karakter kitinase hasil isolasi yang meliputi pH optimum dan suhu optimum. Kitinase adalah enzim kompleks terdiri dari endokitinase, kitobiosidase dan $\mathrm{N}$-asetilglukosaminidase. Media produksi mengandung kitin koloidal sebagai inducer. Fraksinasi dilakukan dengan amonium sulfat sampai tingkat kejenuhan 90\% (F5). Aktivitas kitinase diukur dengan metode Ueda-Arai berdasarkan pengurangan substrat. Aktivitas spesifik paling tinggi diperoleh pada fraksi satu (F1) yaitu sebesar 73,258 U/mg. Hasil karakterisasi kitinase diperoleh profil pH optimum kitinase pada $\mathrm{pH}$ 3,8 sedangkan profil suhunya diperoleh dua puncak yaitu pada $28,5^{\circ} \mathrm{C}$ dan $29,5^{\circ} \mathrm{C}$. Profil suhu dua puncak/titik menunjukkan jika kemungkinan terdapat dua jenis kitinase pada enzim yang diuji.

\section{Pendahuluan}

Kitinase adalah enzim golongan glikosil hidrolase yang mengkonversi kitin menjadi monomernya yakni $\mathrm{N}$-asetil glukosamin yang dapat digunakan sebagai substrat dalam berbagai aplikasi industri $[1,2]$. N-asetil glukosamin merupakan komponen dari glikoprotein dan glikosaminoglikan yang berperan sebagai substrat untuk perbaikan jaringan dan reaksi anti-inflamasi [3].
$\mathrm{N}$-asetil glukosamin memiliki aktivitas anti-inflamasi pada kondrosit manusia untuk mengatasi gejala osteoartritis [4]. Selain itu, N-asetil glukosamin juga diaplikasikan pada kosmetik untuk mencegah hiperpigmentasi, penuaan dan menjaga elastisitas kulit [5]. Semua enzim yang dapat mendegradasi kitin disebut sebagai kitinase total atau kitinase non spesifik. Berdasarkan mode of action, kitinase dapat diklasifikasikan ke dalam dua kategori utama, 
endokitinase (EC.3.2.1.14) dan eksokitinase yang terdiri dari kitobiohidrolase dan $\mathrm{N}$-asetilglukosaminidase (EC.3.2.1.30) [6]. Endokitinase menghidrolisis kitin secara acak dari bagian dalam menghasilkan kitooligomer. Eksokitinase terdiri dari kitobiohidrolase yang menghidrolisis kitin secara berurutan dari ujung nonreduksi menghasilkan kitobiosa sebagai produk akhir dan $\beta$-N-asetilheksosaminidase yang menghidrolisis kitin secara berurutan dari ujung nonreduksi menghasilkan N-asetilglukosamin [7]. Saat ini, kitinase banyak diaplikasikan dalam bidang pertanian dan bioteknologi. Kitinase dapat digunakan sebagai agen biokontrol untuk jamur patogen, menghambat kerusakan makanan kemasan dan sebagai insektisida [8]. Selain itu, kitinase diantaranya juga digunakan sebagai biokontrol larva nyamuk, preparasi protoplats, produksi protein sel tunggal dari limbah perikanan, produksi senyawa kitooligosakarida dan $\mathrm{N}-$ asetilglukosamin [7, 9].

Sumber kitinase dari golongan mikroorganisme misalnya adalah bakteri Bacillus sp. DAU101 [10], Enterobacter sp. NRG4 [9]. Organisme lain yang dapat menghasilkan kitinase adalah aktinomiset [11]. Kitinase juga dapat ditemukan pada jamur Trichoderma viride [12].

Salah satu jamur yang memiliki potensi sebagai sumber kitinase adalah jamur akuatik. Jamur akuatik adalah jamur yang hidup dalam habitat berair. Jamur akuatik kitinolitik merupakan jamur akuatik yang memiliki kemampuan untuk menghasilkan kitinase sehingga mampu mendegradasi kitin. Al-Rekabi, dkk (2005) melaporkan kemampuan kitinolitik dari dua jamur akuatik yaitu Saprolegnia turfosa dan Achlya sp. Isolat jamur akuatik KC3 koleksi Laboratorium Mikrobiologi Jurusan Biologi FSM Undip juga berpotensi menjadi sumber kitinase. Jamur akuatik ini telah berhasil diisolasi oleh tim penelitian tematik DBD FSM Undip dari bangkai kecoa yang ditempatkan dalam air. Kecoa merupakan spesies serangga dari ordo orthoptera. Tubuh kecoa mengandung kitin sebesar 35\% [13]. Karena itu, jamur akuatik KC3 mampu tumbuh pada bangkai kecoa dengan mendegradasi kitin pada tubuh kecoa sebagai sumber karbon dan nitrogen untuk pertumbuhannya

Penelitian ini bertujuan untuk mendapatkan kitinase yang diisolasi dari jamur akuatik kitinolitik KC3 dan mendapatkan informasi karakteristik kitinase hasil isolasi yang meliputi $\mathrm{pH}$ dan suhu optimum.

\section{Metode Penelitian}

\section{Alat dan Bahan}

Peralatan yang digunakan dalam penelitian ini adalah peralatan gelas laboratorium kimia, autoklaf (Napco Model 8ooo-DSE), mikropipet (Nichiryo Model 500oF), sentrifus (Centrific-228), Spektrofotometer UVVis (T6ou Spectrometer), Shaker incubator (ES-20 Giant), neraca analitik (Kern), oven (LG), kompor listrik (Maspion). Bahan yang digunakan dalam penelitian ini adalah biakan murni jamur akuatik KC3 koleksi Laboratorium Mikrobiologi Jurusan Biologi FSM Undip, koloidal kitin, $\mathrm{KH}_{2} \mathrm{PO}_{4}, \mathrm{NaNO}_{3}, \mathrm{BaCl}_{2}, \mathrm{MgSO}_{4} \cdot 7 \mathrm{H}_{2} \mathrm{O}$,
$\mathrm{CuSO}_{4}$, Kalium natrium tartrat, $\mathrm{KCl}, \mathrm{FeSO}_{4}$, pepton, yeast extract, BSA, Follin-Ciocalteau, bufer asetat 0,2 M, $\left(\mathrm{NH}_{4}\right)_{2} \mathrm{SO}_{4}$.

\section{Peremajaan dan Aktivasi Jamur Akuatik KC3}

Jarum ose yang telah disterilkan dengan autoklaf dan pemijaran digoreskan pada spora biakan murni sel jamur akuatik dari stok awal media agar miring. Kemudian secara aseptik spora tersebut diinokulasikan pada media padat kitin yang terdiri dari $\mathrm{KH}_{2} \mathrm{PO}_{4} 0,1 \%$, $\mathrm{MgSO}_{4.7} 7 \mathrm{H}_{2} \mathrm{O} 0,05 \%, \mathrm{KCl} 0,05 \%$, agar $3 \%$ dan kitin koloidal $0,5 \%$. Media yang telah diinokulasi dengan spora jamur kemudian diinkubasi pada suhu ruang di inkubator. Tahap selanjutnya sebanyak satu mata jarum ose dari hasil peremajaan yang sudah tumbuh pada media padat kitin diinokulasikan pada media cair yang mengandung komposisi seperti tabel I, kemudian dilakukan inkubasi pada inkubator shaker selama 3 hari dengan kecepatan $50 \mathrm{rpm}$.

Tabel 1: Komposisi $100 \mathrm{~mL}$ media fermentasi cair

\begin{tabular}{cc}
\hline Bahan & gram \\
\hline Koloidal kitin & 1,5 \\
$\mathrm{NaNO}_{3}$ & 0,2 \\
$\mathrm{KH}_{2} \mathrm{PO}_{4}$ & 0,1 \\
$\mathrm{MgSO}_{4} \cdot 7 \mathrm{H}_{2} \mathrm{O}$ & 0,05 \\
$\mathrm{FeSO}_{4 \cdot 7} \cdot 7 \mathrm{H}_{2} \mathrm{O}$ & 0,05 \\
$\mathrm{KCl}$ & 0,05 \\
Yeast extract & 0,25 \\
Pepton & 0,25 \\
\hline
\end{tabular}

\section{Pembuatan Kurva Pertumbuhan}

Sebanyak 10 buah botol gelas masing-masing diisi dengan $20 \mathrm{~mL}$ media cair dengan komposisi seperti pada tabel I dalam bufer asetat $\mathrm{pH}$ 5, kemudian disterilisasi dengan autoklaf selama 20 menit. Pada 10 buah botol gelas masing-masing ditambahkan $0,8 \mathrm{~mL}$ inokulum jamur akuatik (sebagai sampel) secara aseptik. Kemudian ke-10 botol tersebut dimasukkan dalam inkubator shaker dengan kecepatan $50 \mathrm{rpm}$ pada suhu ruang, selanjutnya sampel diambil tiap 6 jam untuk diukur berat keringnya. Penentuan kurva pertumbuhan jamur akuatik dilakukan dengan menggunakan metode pengukuran berat kering sel. Data yang didapatkan adalah jumlah berat kering sel jamur. Data yang diperoleh kemudian diplotkan terhadap waktu sehingga diperoleh grafik waktu vs jumlah berat kering sel jamur.

\section{Produksi Kitinase}

Produksi kitinase diawali dengan membuat media starter sebanyak $50 \mathrm{~mL}$ dengan langkah sama seperti tahap aktivasi pada media cair. Sebanyak $10 \mathrm{~mL}$ starter jamur akuatik KC3 dipindahkan secara aseptik kedalam media produksi $250 \mathrm{~mL}$ ( $4 \%$ starter). Komposisi media produksi sama dengan komposisi media starter dengan komposisi seperti tabel I. Media produksi diinkubasi pada shaker incubator. Setelah mencapai waktu sesuai fase log, media produksi disaring menggunakan kertas saring untuk memisahkan sel jamur akuatik dengan media produksi. Media produksi selanjutnya 
disentrifugasi dengan kecepatan $5000 \mathrm{rpm}$ pada suhu $5^{\circ} \mathrm{C}$ selama 30 menit untuk memisahkan filtrat (ekstrak kasar kitinase) dan endapan.

\section{Fraksinasi Kitinase dengan Amonium Sulfat}

Amonium sulfat ditambahkan kedalam ekstrak kasar enzim sambil diaduk dengan magnetic stirrer dengan kecepatan lambat sampai padatan amonium sulfat larut sempurna. Tingkat kejenuhan amonium sulfat $0-20 \%$ dikelompokkan menjadi $\mathrm{F} 1,20-40 \% \mathrm{~F} 2$, 40-60\% F3, 60-80\% F4 dan 80-90\% F\%. Campuran tersebut didiamkan selama satu malam dalam keadaan dingin. Selanjutnya campuran disentrifugasi dengan kecepatan $5000 \mathrm{rpm}$ selama 20 menit pada suhu $5^{\circ} \mathrm{C}$. Hasil sentrifugasi akan diperoleh endapan yang terpisah dari filtratnya. Endapan diambil dan disuspensikan dengan bufer asetat 0,2 M pH 5. Filtrat yang diperoleh kemudian dilanjutkan dengan perlakuan yang sama untuk fraksi berikutnya.

\section{Dialisis Kitinase}

Membran selofan yang berisi enzim direndam dalam $800 \mathrm{~mL}$ bufer asetat 0,0002 $\mathrm{M} \mathrm{pH} \mathrm{5,0} \mathrm{lalu} \mathrm{diaduk}$ dengan magnetic stirer dalam kondisi dingin. Tiap dua jam bufer diganti serta diuji kandungan amonium sulfatnya dengan $\mathrm{BaCl}_{2}$ sampai tidak terbentuk endapan putih. Pada tahap ini diperoleh kitinase F1 bebas amonium sulfat. Perlakuan yang sama diterapkan pada F2, F3, F4 dan F5, untuk mendapatkan enzim kitinase F2, F3, F4 dan F5 yang bebas amonium sulfat.

\section{Penentuan Aktivitas Kitinase}

Aktivitas kitinase diuji menurut metode Veda dan Arai [14] dengan substrat koloidal kitin. Sebanyak 1,0 mL koloidal kitin 0,3\%, 2,0 mL bufer asetat 0,2 $\mathrm{M} \mathrm{pH} 5$ dan $1,0 \mathrm{~mL}$ filtrat enzim dimasukkan kedalam tabung reaksi dan diinkubasi pada suhu ruang selama waktu tertentu. Kemudian campuran tersebut dipanaskan dalam air mendidih selama 20 menit untuk menghentikan reaksi enzimatis dalam campuran tersebut lalu didinginkan. Aktivitas enzim dalam campuran tersebut ditentukan secara spektrofotometri pada $\lambda=660 \mathrm{~nm}$.

$$
\begin{aligned}
\text { Unit aktivitas }= & \frac{x-y}{0,001} \times \frac{1}{\text { waktu inkubasi (menit) }} \\
\text { Keterangan: } \mathrm{x} & =\text { serapan kontrol } \\
\mathrm{y} & =\text { serapan sampel }
\end{aligned}
$$

\section{Penentuan Kadar Protein}

Kadar protein total enzim ditentukan dengan metode Lowry, menggunakan BSA sebagai larutan standar.

\section{Penentuan Aktivitas Spesifik Kitinase}

Aktivitas spesifik kitinase ditentukan dengan menghitung unit aktivitas kitinase dibagi dengan kadar protein total.

\section{Karakterisasi Kitinase}

Penentuan pH optimum dilakukan dengan mereaksikan $1 \mathrm{~mL}$ kitinase ditambah $1 \mathrm{~mL}$ substrat koloidal kitin $0,3 \%$ yang telah dilarutkan dalam bufer asetat $0,2 \mathrm{M}$ dengan variasi $\mathrm{pH} 3,6 ; 3,8 ; 4,0 ; 4,2 ; 4,4$ ditambah buffer asetat $0,2 \mathrm{M}$ sesuai dengan variasi $\mathrm{pH}$ tersebut sebanyak $2 \mathrm{~mL}$, kemudian diinkubasi pada suhu ruang selama 90 menit. Hasil inkubasi kemudian dipanaskan dalam air mendidih selama 20 menit. Aktivitas enzim dalam campuran tersebut ditentukan secara spektrofotometri pada $\lambda=660 \mathrm{~nm}$.

Setelah diperoleh $\mathrm{pH}$ optimum, dilakukan penentuan suhu optimum. Sebanyak $1 \mathrm{~mL}$ kitinase hasil fraksinasi ditambah $1 \mathrm{~mL}$ substrat koloidal kitin 0,3\% yang telah dilarutkan dalam bufer asetat $0,2 \mathrm{M}$ pada $\mathrm{pH}$ optimum yang telah diperoleh sebelumnya, kemudian diinkubasi selama 90 menit dengan variasi suhu inkubasi $28^{\circ} \mathrm{C}, 28,5^{\circ} \mathrm{C}, 29^{\circ} \mathrm{C}, 29,5^{\circ} \mathrm{C}$, dan $30,0^{\circ} \mathrm{C}$. Hasil inkubasi kemudian dipanaskan dalam air mendidih selama 20 menit. Aktivitas enzim dalam campuran tersebut ditentukan secara spektrofotometri pada $\lambda=$ $660 \mathrm{~nm}$.

\section{Hasil dan Pembahasan}

\section{Peremajaan dan Aktivasi Jamur Akuatik Kitinolitik} $\mathrm{KC} 3$

Peremajaan dilakukan pada media padat mengandung kitin. Peremajaan dilakukan 2 kali agar diperoleh sel jamur yang semakin murni dan bebas dari kontaminasi mikroba lainnya. Peremajaan akan menghasilkan sel yang lebih muda. Media yang digunakan untuk peremajaan adalah media padat, sedangkan media untuk produksi adalah media cair, karena itu sel jamur akuatik dari media peremajaan diaktivasikan pada media cair terlebih dulu. Media cair yang digunakan mengandung kitin koloidal. Kandungan kitin pada media cair akan menjadi inducer sehingga sel jamur mensekresikan kitinase untuk memecah kitin pada media.

\section{Pembuatan Kurva Pertumbuhan Jamur Akuatik KC3}

Kurva pertumbuhan menunjukkan fase-fase pertumbuhan mikroorganisme. Jika fase hidup sel jamur akuatik diketahui akan memudahkan proses isolasi kitinase. Enzim biasanya diisolasi pada fase log karena pada fase ini sel jamur sedang mengalami pertumbuhan yang cukup pesat dengan jumlah sel yang banyak. Jika jumlah sel yang tumbuh banyak maka enzim yang dihasilkan juga banyak karena masing-masing sel mensekresikan enzim. Kurva pertumbuhan yang diperoleh dapat dilihat pada gambar I.

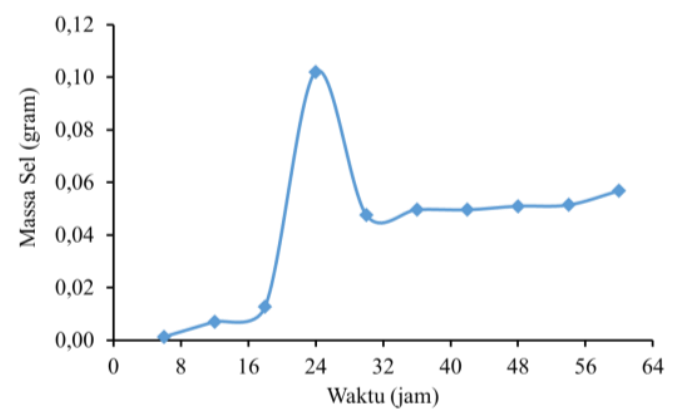

Gambar 1. Kurva Pertumbuhan Jamur Akuatik Kitinolitik KC3 
Pada gambar 1 dapat dilihat terjadi peningkatan massa sel secara signifikan pada jam ke-24, kemudian menurun drastis pada jam ke-30. Kurva yang diperoleh tidak memiliki fase stasioner, mungkin karena rentang waktu pengukuran masih terlalu lebar sehingga fase stasioner tidak diperoleh. Lonjakan massa sel yang signifikan mungkin juga disebabkan karena adanya pengaruh dari sisa-sisa media (terutama kitin koloidal) yang tidak larut dalam bufer. Sisa media yang tidak larut ataupun tidak digunakan oleh jamur dapat mempengaruhi pengukuran berat sel karena metode yang digunakan dalam pembuatan kurva pertumbuhan ini menggunakan pengukuran berat kering sel jamur. Kurva pertumbuhan isolat jamur tersebut perlu diteliti lebih lanjut dengan mempersempit rentang waktu pengukuran dan memperbesar volume media pertumbuhan yang digunakan untuk menghindari terbawanya sisa media saat penyaringan. Waktu panen yang tepat berdasarkan kurva pertumbuhan di atas adalah jam ke-24 karena pada jam ini massa sel paling besar dengan demikian diharapkan jumlah enzim yang disekresikan juga besar

\section{Produksi Kitinase}

Tahap awal proses produksi adalah pembuatan starter. Starter adalah biakan yang siap difermentasikan. Starter memenuhi syarat untuk difermentasikan karena telah dikondisikan sesuai dengan kondisi fermentasi produksi. Media untuk starter dibuat dengan komposisi yang sama dengan media untuk produksi. Selain komposisi media, suhu inkubasi dan kecepatan incubator shaker juga sama. Penggunaan starter akan mempercepat waktu produksi karena fase adaptasi menjadi lebih singkat.

Saat proses produksi berlangsung, kitinase disekresikan keluar sel oleh jamur akuatik untuk memecah kitin menjadi unit yang lebih kecil. Hasil hidrolisis kitin digunakan oleh jamur akuatik sebagai sumber karbon dan nitrogen untuk menunjang pertumbuhannya. Kitinase yang telah disekresikan ke luar sel akan bercampur dengan media produksi, karena itu untuk memperoleh kitinase dilakukan penyaringan media produksi. Sel jamur dan sisa media akan terpisah dengan filtrat yang mengandung kitinase.

\section{Fraksinasi dengan Amonium Sulfat}

Penambahan amonium sulfat dapat menurunkan kelarutan protein melalui dua mekanisme yaitu salting in dan salting out. Salting in terjadi pada saat konsentrasi garam rendah, ion garam yang dihasilkan akan melindungi molekul-molekul protein dan mencegah bersatunya molekul-molekul protein sehingga protein tetap melarut. Salting out terjadi pada saat konsentrasi garam tinggi, ion yang dihasilkan akan meningkatkan muatan listrik di sekitar protein yang mengakibatkan tertariknya mantel air dari koloid protein sehingga interaksi hidrofobik di antara sesama molekul protein menurunkan kelarutan protein.

Protein yang mengendap pada fraksi satu sebagian besar adalah protein yang mengandung asam-asam amino hidrofobik yang cukup banyak, karena itu pada penambahan garam dengan konsentrasi kecil (0-20\%) sudah dapat mengendap. Semakin besar konsentrasi garam yang diperlukan untuk mengendapkan protein berarti kandungan asam aminonya semakin banyak yang hidrofilik.

\section{Dialisis Kitinase}

Fraksi kitinase yang diperoleh dari fraksinasi bertingkat masih mengandung amonium sulfat, untuk memisahkan amonium sulfat dari protein dapat dilakukan dengan dialisis menggunakan membran selofan [15]. Dialisis adalah suatu cara yang digunakan untuk desalinasi enzim secara difusi melalui membran semipermeabel berpori dengan ketebalan 10-100 $\mu \mathrm{m}$, dimana pemisahannya berdasarkan gradien konsentrasi. Konsentrasi bufer asetat yang terdapat dalam kantung membran selofan adalah 0,2 $\mathrm{M}$, sedangkan bufer asetat di luar membran 0,002 $\mathrm{M}$. Perbedaan konsentrasi akan menyebabkan difusi, molekul-molekul yang berukuran kecil seperti sisa-sisa garam amonium sulfat akan keluar dari membran, sedangkan molekul besar seperti protein akan tetap berada di dalam membran. Proses dialisis terus dilakukan sampai protein enzim dalam membran terbebas dari amonium sulfat, untuk mengetahui hal tersebut, bufer di luar membran diambil sekitar 1-2 mL kemudian direaksikan dengan $\mathrm{BaCl}_{2}$. Jika masih terbentuk endapan putih berarti protein enzim dalam membran belum terbebas dari amonium sulfat. Endapan putih tersebut terbentuk dari reaksi antara $\mathrm{Ba}^{2+}$ dan $\mathrm{SO}_{4}{ }^{2-}$ membentuk endapan putih $\mathrm{BaSO}_{4}$.

\section{Uji Aktivitas Kitinase}

Aktivitas kitinase yang diukur merupakan aktivitas kitinase total atau non-spesifik, yakni meliputi aktivitas endokitinase maupun eksokitinase [16]. Produk yang dihasilkan adalah kitooligosakarida dan Nasetilglukosamin. Aktivitas kitinase diuji dengan metode Veda dan Arai [14] berdasarkan pengurangan substrat koloidal kitin. Turbiditas yang disebabkan karena berkurangnya jumlah kitin di dalam campuran reaksi diukur absorbansinya pada panjang gelombang $660 \mathrm{~nm}$. Satu unit aktivitas enzim diukur sebagai sejumlah enzim yang mengakibatkan pengurangan absorbansi campuran reaksi sebesar 0,001 pada $660 \mathrm{~nm}$ tiap menit.

Kadar total protein enzim diukur dengan metode Lowry dkk. [17] dengan menggunakan panjang gelombang maksimum larutan standar BSA yang sebelumnya telah diperoleh dari pengukuran yaitu 732 nm. Standar yang digunakan BSA karena BSA tersusun atas semua asam amino yang lengkap.

Metode Lowry $d k k$. [17] dipilih karena lebih mudah dan sensitif terhadap residu protein sistein, tirosin dan triptofan. Prinsip metode Lowry adalah reaksi pembentukan kompleks antara nitrogen pada ikatan peptida dengan ion $\mathrm{Cu}^{2+}$ pada suasana basa dan reduksi fosfomolibdat serta fosfotungstat pada reagen Follinciocalteu oleh rantai samping asam amino tirosin dan triptofan [18]. Jika unit aktivitas suatu fraksi semakin tinggi dan kadar protein totalnya semakin rendah, akan 
semakin tinggi nilai aktivitas spesifiknya. Unit aktivitas kitinase dapat dilihat pada gambar 2, sedangkan aktivitas spesifik kitinase disajikan pada gambar 3.

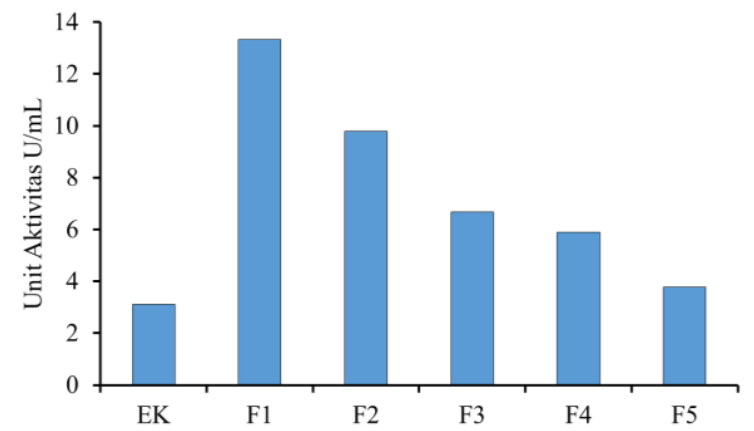

Gambar 2. Grafik Unit Aktivitas Kitinase

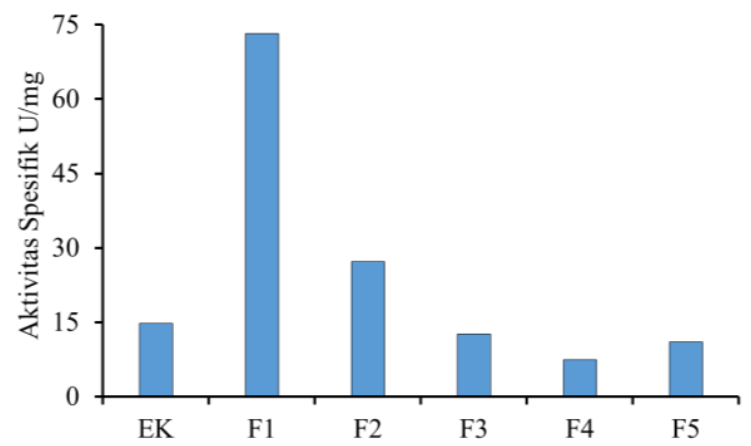

Gambar 3. Grafik aktivitas spesifik kitinase

Fraksi yang memiliki aktivitas spesifik tertinggi adalah F1. Hal ini berarti sebagian besar protein yang terendapkan pada F1 adalah protein kitinase. Fraksi dengan aktivitas spesifik tertinggi selanjutnya dikarakterisasi $\mathrm{pH}$ dan suhu optimumnya.

\section{pH Optimum}

Sebagian besar kitinase dari mikroba memiliki kondisi optimum pada rentang $\mathrm{pH}$ 3,5-9 [6]. Beberapa hasil penelitian menyebutkan jika kitinase dari Penicillium sp. LYG 0704 memiliki pH optimum 5 [19], sedangkan pada Isaria fumosorosea memiliki $\mathrm{pH}$ optimum 5,7 [20]. Hasil penelitian Sharaf dkk. [12] menyebutkan jika kondisi optimum kitinase dari Trichoderma viride diperoleh pada $\mathrm{pH}$ 4. Hasil karakterisasi $\mathrm{pH}$ diperoleh $\mathrm{pH}$ optimum kitinase adalah $\mathrm{pH}$ 3,8 dengan unit aktivitas sebesar 7,333 U/mL. Kondisi pH optimum kitinase dapat dilihat pada gambar berikut ini.

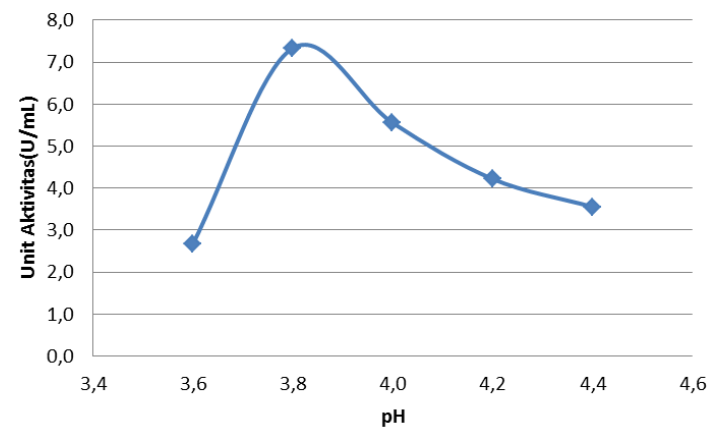

Gambar 4. Grafik pH optimum
Perubahan muatan pada enzim dapat mempengaruhi aktivitasnya, baik dengan perubahan struktur maupun perubahan muatan pada residu asam amino yang memiliki kemampuan katalitik. Perubahan ion $\mathrm{H}^{+}$yang ada dalam larutan enzim memberikan pengaruh pada konformasi bagian katalitik enzim. Jika pH terlalu rendah atau terlalu tinggi akan menyebabkan perubahan konformasi enzim sehingga aktivitas enzim menurun. Perubahan pH yang ekstrim akan menyebabkan enzim mengalami denaturasi karena terganggunya interaksi-interaksi nonkovalen yang menjaga kestabilan struktur tiga dimensi enzim [21].

\section{Suhu Optimum}

Di lingkungan alami, aktivitas enzim yang diproduksi mikroorganisme mesofil (termasuk kitinase) umumnya tidak melampaui temperatur $30^{\circ} \mathrm{C}$ [22]. Hasil penelitian Sharaf $d k k$. [12] menyebutkan kitinase yang diperoleh dari Tricoderma Viridae memiliki suhu optimum yang tidak berbeda jauh yaitu $28^{\circ} \mathrm{C}$

Kitinase merupakan enzim kompleks yang terdiri dari endokitinase, kitobiosidase dan Nasetilglukosaminidase. Satu spesies organisme mampu menghasilkan lebih dari satu kitinase. Organisme dengan kemampuan menghasilkan lebih dari satu kitinase bukan sesuatu yang baru. Bakteri Pseudomonas aeuroginosa K-187 dilaporkan menghasilkan dua kitinase yang masing-masing memiliki suhu optimum $50^{\circ} \mathrm{C}$ dan $40^{\circ} \mathrm{C}$, sedangkan $\mathrm{pH}$ optimumnya pada $\mathrm{pH} 8$ dan 7 [23]. Bacillus sp MH-1 menghasilkan tiga kitinase, dua diantaranya memiliki suhu optimum yang sama yaitu $75^{\circ} \mathrm{C}$ sedangkan $\mathrm{pH}$ optimumnya 5,5 dan 6,5 [24]. Isolat jamur akuatik kitinolitik $\mathrm{KC} 3$ kemungkinan juga mampu menghasilkan lebih dari satu kitinase. Hal ini dapat dilihat dari hasil karakterisasi suhu optimum kitinase yang ditunjukkan pada gambar $\mathrm{V}$ terdapat dua puncak menunjukkan bahwa kemungkinan terdapat lebih dari satu kitinase pada enzim yang diuji.

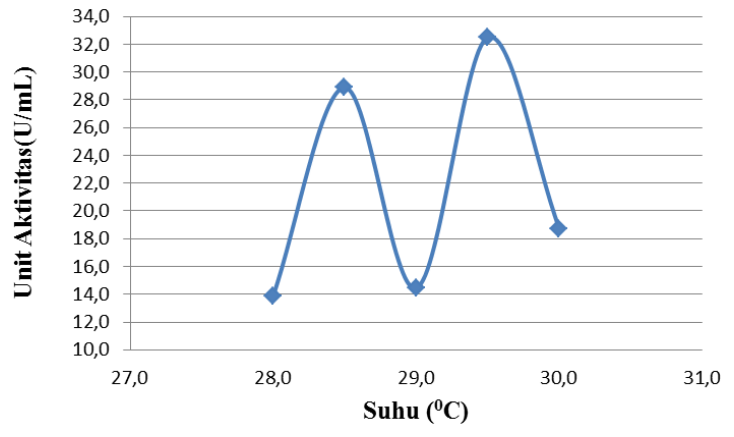

Gambar 5. Grafik suhu optimum

Temperatur ketika aktivitas enzim cukup besar disebut temperatur optimum. Pada suhu optimum substrat akan lebih sering bertumbukan dengan sisi aktif enzim sehingga pembentukan kompleks enzimsubstrat optimal. Berdasarkan profil suhu yang diperoleh suhu optimum kitinase jamur akuatik kitinolitik KC3 adalah $28,5^{\circ} \mathrm{C}$ dan $29,5^{\circ} \mathrm{C}$.

Enzim merupakan suatu protein, jika suhu terlalu tinggi dapat menyebabkan terjadinya proses denaturasi. Jika suatu protein terdenaturasi, maka susunan tiga 
dimensi khas dari rantai polipeptida terganggu dan molekul ini terbuka menjadi struktur acak, tanpa adanya kerusakan pada struktur kerangka kovalen. Protein yang terdenaturasi dapat membentuk berbagai bentuk acak yang biasanya tidak aktif [25]. Perubahan bentuk ini menyebabkan aktivitas enzim menurun, karena sisi aktif kehilangan kemampuan katalitiknya sehingga produk yang dihasilkan juga sedikit.

\section{Kesimpulan}

Kitinase dapat diisolasi dari isolat jamur akuatik kitinolitik KC3 dengan menggunakan kitin koloidal sebagai inducer. Kondisi optimum reaksi enzimatis kitinase hasil isolasi adalah pada suhu $28,5^{\circ} \mathrm{C}$ dan $29,5^{\circ} \mathrm{C}$ serta $\mathrm{pH}$ 3,8. Setiap mikroorganisme memiliki karakter yang berbeda sehingga kemampuan menghasilkan kitinase dan karakter kitinase yang dihasilkan juga berbeda. Oleh karena itu, penting untuk dilakukan identifikasi isolat yang digunakan karena dapat membuka ruang eksplorasi kitinase lebih luas. Mikroorganisme yang memiliki hubungan kekerabatan dekat biasanya juga mampu menghasilkan enzim yang sama.

\section{Daftar Pustaka}

[1] Magdalena A Gutowska, Jeffrey C Drazen, Bruce H Robison, Digestive chitinolytic activity in marine fishes of Monterey Bay, California, Comparative Biochemistry and Physiology Part A: Molecular \& Integrative Physiology, 139, 3, (2004) 351-358 http://dx.doi.org/10.1016/j.cbpb.2004.09.020

[2] Gemma Reguera, Susan B Leschine, Biochemical and genetic characterization of ChiA, the major enzyme component for the solubilization of chitin by Cellulomonas uda, Archives of microbiology, 180, 6, (2003) 434-443 http://dx.doi.org/10.1007/s00203003-0611-y

[3] Jeen-Kuan Chen, Chia-Rui Shen, Chao-Lin Liu, Nacetylglucosamine: production and applications, Marine drugs, 8, 9, (2010) 2493-2516 http://dx.doi.org/10.3390/md8092493

[4] Alexander R Shikhman, Klaus Kuhn, Nada Alaaeddine, Martin Lotz, N-acetylglucosamine prevents IL-1 $\beta$-mediated activation of human chondrocytes, The Journal of Immunology, 166, 8, (2001)

$5155-5160$ http://dx.doi.org/10.4049/jimmunol.166.8.5155

[5] Donald L Bissett, Larry R Robinson, Patricia S Raleigh, Kukizo Miyamoto, Tomohiro Hakozaki, Jim $\mathrm{Li}$, Gary R Kelm, Reduction in the appearance of facial hyperpigmentation by topical $\mathrm{N}$ - acetyl glucosamine, Journal of cosmetic dermatology, 6, 1, (2007) 20-26 http://dx.doi.org/10.1111/j.14732165.2007.00295.x

[6] Winda Haliza, Maggy Thenawidjaya Suhartono, Karakteristik kitinase dari mikrobia, Buletin Teknologi Pasca Panen, 8, 1, (2016) 1-14

[7] Reetarani S. Patil, Vandana Ghormade, Mukund V. Deshpande, Chitinolytic enzymes: an exploration, Enzyme and Microbial Technology, 26, 7, (2000) 473483 0229(00)00134-4
[8] Luis Morales de la Vega, J Eleazar Barboza-Corona, Maria G Aguilar-Uscanga, Mario Ramírez-Lepe, Purification and characterization of an exochitinase from Bacillus thuringiensis subsp. aizawai and its action against phytopathogenic fungi, Canadian Journal of Microbiology, 52, 7, (2006) 651-657 http://dx.doi.org/10.1139/w06-019

[9] Neetu Dahiya, Rupinder Tewari, Gurinder Singh Hoondal, Biotechnological aspects of chitinolytic enzymes: a review, Applied Microbiology and Biotechnology, 71, 6, (2006) 773-782 http://dx.doi.org/10.1007/s00253-005-0183-7

[10] Yong-Seok Lee, In-Hye Park, Ju-Soon Yoo, SooYeol Chung, Young-Choon Lee, Young-Su Cho, Soon-Cheol Ahn, Cheol-Min Kim, Yong-Lark Choi, Cloning, purification, and characterization of chitinase from Bacillus sp. DAU101, Bioresource Technology, 98, 14, (2007) 2734-2741 http://dx.doi.org/10.1016/j.biortech.2006.09.048

[11] MS Hosny, NA El-Shayeb, Amira Abood, AM AbdelFattah, A potent chitinolytic activity of marine Actinomycete sp. and enzymatic production of chitooligosaccharides, Australian Journal of Basic and Applied Sciences, 4, 4, (2010) 615-623

[12] Eman Fathi Sharaf, Abd El-Aziz Qablan El-Sarrany, Mai El-Deeb, Biorecycling of shrimp shell by Trichoderma viride for production of antifungal chitinase, African Journal of Microbiology Research, 6, 21, (2012) 4538-4545 http://dx.doi.org/10.5897/AJMR12.148

[13] Riccardo AA Muzzarelli, Chitin, Elsevier, 2013.

[14] Mitsuhiro Veda, Motoo Arai, Purification and some properties of chitinases from Aeromonas sp. No. 10S-24, Bioscience, biotechnology, and biochemistry, 56, 3, (1992) 460-464 http://dx.doi.org/10.1271/bbb.56.460

[15] Felix Franks, Characterization of Proteins, Humana Press, 1988.

[16] H Bielka, HBF Dixon, P Karlson, C Liebecq, N Sharon, EJ Van Lenten, SF Velick, JFG Vliegenthart, EC Webb, A Cornish-Brown, Enzyme nomenclature, in, Academic Press, New York, 1984.

[17] Oliver H Lowry, Nira J Rosebrough, A Lewis Farr, Rose J Randall, Protein measurement with the Folin phenol reagent, The Journal of biological chemistry, 193, 1, (1951) 265-275

[18] Keith Wilson, John Walker, Principles and techniques of practical biochemistry, Cambridge University Press, 2000.

[19] Yoon Gyo Lee, Ki-Chul Chung, Seung Gon Wi, Jae Chang Lee, Hyeun-Jong Bae, Purification and properties of a chitinase from Penicillium sp. LYG 0704, Protein Expression and Purification, 65, 2, (2009) $244-250$ http://dx.doi.org/10.1016/j.pep.2008.12.004

[20]Shaukat Ali, Jianhui Wu, Zhen Huang, Shun Xiang Ren, Production and regulation of extracellular chitinase from the entomopathogenic fungus Isaria fumosorosea, Biocontrol science and technology, 20, 7, (2010) 723-738 http://dx.doi.org/10.1080/09583151003714091

[21] BD Hames, NM Hooper, Biochemistry: The Instant Notes. 2nd editioin, Hongkong: Spinger-Verlag, (2000) 
[22]Maria Swiontek Brzezinska, Elżbieta LALKEPORCZYK, Wojciech Donderski, Maciej Walczak, Degradation of chitin in natural environment: role of actinomycetes, Pol. J. Ecol, 57, 2, (2009) 229-238

[23] San-Lang Wang, Wen-Tsu Chang, Purification and characterization of two bifunctional chitinases/lysozymes extracellularly produced by Pseudomonas aeruginosa $\mathrm{K}-187$ in a shrimp and crab shell powder medium, Applied and environmental microbiology, 63, 2, (1997) 380-386

[24]Kenji Sakai, Akira Yokota, Hajime Kurokawa, Mamoru Wakayama, Mitsuaki Moriguchi, Purification and characterization of three thermostable endochitinases of a noble Bacillus strain, $\mathrm{MH}-1$, isolated from chitin-containing compost, Applied and Environmental Microbiology, 64, 9, (1998) 3397-3402

[25]Albert L Lehninger, Dasar-Dasar Biokimia, M. Thenawidjaja, Erlangga, Jakarta, 1990. 